\title{
Rustamov K.E.
}

DOI: 10.25108/2304-1730-1749.iolr.2015.45.153-168

\section{Problems of providing the rights of person during using special knowledge in a court of first instance}

\begin{abstract}
It is considered the problems of ensuring the rights of person under using of special knowledge in a court of the first instance.

There declarative nature has participation of an expert, who gave a report at time of pre-trial production, in interrogation of accused, victim, witnesses and production of other investigative actions.

The CPC provisions analysis made in respect of conducting of expertise shows declarative nature of number of provisions, and absence of correlations with other provisions of acting legislation.
\end{abstract}

Keywords: special knowledge; court; expert; expert report; specialist; pre-trial production; material evidences.

Using of special knowledge in a court of first instance is come down to assignment of expertise, interrogation of an expert and specialist as a witness, participation of them in inspection of land and rooms, present for identification, investigative experiment and seizure of the samples for research.

According to article 331 of the $\mathrm{CPC}$, if during pre-trial production the expert examination was conducted then in course of trial examination is investigated a record given by an expert at the stage of pre-trial production.

The expert, who gave the record during pre-trial production, has the right to participate in court proceedings and examination of the evidences, which have an attitude to the expert examination's subject; to take part in interrogation of accused,

\footnotetext{
- Rustamov Kamran Elkhan oglu - a dissertator of Forensic Science Centre of the Ministry of Justice, a member of the International Organization for Legal Researches (Azerbaijan). E-mail: kamran39@rambler.ru
} 
victim, witnesses, examination of material evidences and production other investigative actions.

It seems that above stated provisions have declarative nature and unfulfilled in practice.

Expert appeared in court session will first of all be questioned as a witness of a record that given by him in pre-trial production.

Participation of a witness in interrogation of accused, victim, other witnesses, examination of material evidences and production other investigative actions are problematic. At the best, there might be produced confrontations, but this is not stipulated by the law.

On completion of a record's examination of expert and receiving an opinion each of parties, a court has the right on appeal of the parties or own initiative to appoint repeated or additional expert examination.

In case, the expert examination was not conducted during pre-trial production then the parties may petition for appointment of expertise in course of court proceedings. In their written petition a party of criminal process has to indicate the issues, on which should be given a record by an expert, what circumstances subject to be clear and suggestions on a matter, who has to be involved as an expert.

Each party of criminal process has the right to familiarize with petition other party on appointment of expert examination and to express their opinion on the matters mentioned in it.

Thus, under appointment of expertise in a court of first instance, a victim receives the rights, by which he/she was deprived in pre-trial production.

Unfortunately, practice shows that in course of court proceedings the court are tried not to appoint expert examinations in order not to delay a process.

Sometimes, this is caused to negative consequences, which are testified with below indicated case.

On July 1, 2001 in compliance with article 333.3 of Criminal Code of Azerbaijan Republic (unauthorized abandonment of military unit or place of service) in respect of Colonel-Lieutenant Huseynov was instituted a criminal case no. 
$16 / 15372$ by a commander of N. military unit. On October 23, 2003 the case was prequalified in article 334.1 (desertion) of the Criminal Code of Azerbaijan Republic.

Huseynov had been serving in Military Forces since 1980. In 1984-1986 he was platoon leader commander in Afghanistan, participated in Karabakh war, repeatedly awarded with military orders and medals, was more than one wounded, treated in hospitals.

In 1995, while a commander of special troop's brigade, Huseynov became systematically feel himself bad and he was treated for lungs and other diseases. In 2000-2001 Huseynov applied repeatedly with report to present him holiday or dismissal, but he was refused in his request from subjective grounds.

In June 2001, once again, being felt him badly Huseynov visited in private clinic, where he was diagnosed - lungs cancer. In July 2001 without notification, Huseynov went to Denmark, where he was placed in hospital and examined and treated with chemical therapy and was twice operated. Till November 2010 he was in treatment in Denmark, and in December Huseynov returned to Baku and visited the military prosecutor's office, where his criminal case on his search was suspended.

Counsel of Huseynov submitted a petition for appointment expert examination in order to establish the time of beginning and development his disease. Response was that there were no concrete parameters of this as the disease development happens in different way in dependent on subjective and objective grounds: of organism of ill man, living conditions, psychological factors etc. In connection with this, there was refused expert examination's appointment.

Therefore, the counsel obtained on demand from Denmark's hospitals the history of Huseynov's treatment, in one of which was noted that the disease begun more than 15 years ago. Since the disease history was compiled in 2001, and then presupposed time of ill was related to 1986-1987.

Nevertheless, Military Court of Baku garrison sentenced Huseynov to conditional imprisonment, on which he was banned to leave abroad for continuation of treatment. 
Later, the verdict was dismissed by Baku Court of Appeal and Huseynov went to Denmark and due to absence of treatment for long time, he was soon dead.

Not knowing this fact, the military prosecutor's office submitted protest on decision of Court of Appeal, but the Supreme Court dismissed this protest [1].

Article 331.7 of the CPC says that if during preliminary investigation for establishing of the circumstances, stipulated with articles 140.0.1-140.0.4 of the CPC, an expert examination was not conducted, then a court has to provide it production. Upon assignment of expert examination, presiding offers to the parties to formulate the questions before an expert, to inform their ideas as for who should be authorized to conduct it and what should be examined. In order to inform their ideas and ask questions, court declares break in court session.

It seems that above stated provision is a declarative and wrong, on core.

Article 140 of the CPC "Circumstances, which established on some evidences" says that in course of criminal process a number of circumstances are established only upon term of preliminary receiving and investigating certain evidences, and namely: a reason of death, level of seriousness and nature of body injuries - a record of an expert in medicine; ability and inability of suspected or accused during commission of anti-social deed to realize actual character and social danger his/her deed (action or inaction) or manage with it due to his /her chronic mental illness, temporary mental disorder, dementia and other mental diseases - a record of an expert in psychiatry; impossibility correct perception and description by a witness or victim the circumstances, which should be established, due to his /her chronic mental illness, temporary mental disorder, dementia and other mental diseases - a record of an expert in psychiatry; establishing the age of victim, suspected or accused if no documents confirm this age - a record of the experts in medicine and psychology; presence of previous conviction to accused person and assigning him/her a certain punishment - a copy of the verdict.

Certainly, some enumerated circumstances might earlier be unknown and to be appeared only during court proceedings that, mainly, concern witnesses, victims and sudden mental illness of accused. 
Though, absence a medical expert's record in a case about reasons of death, level of seriousness and nature of bodily injuries, documents about the age of accused and presence or absence previous conviction of his/her, cannot be or any case might not be a subject of examination during court examination as these issues should be solved in preparatory hearing of a court. Contrary is a gross violation of the person's rights under using of special knowledge in criminal process, which began in pre-trial and being continued in court productions.

According to article 331.8 of CPC, the parties have the right to present in a court items and documents as objects of expert examination, but the law does not say clear whether they are recognized material evidences. So, according to article 128.2 of the $\mathrm{CPC}$, an item is recognized with material evidence on decision of a body, which carries out criminal process. Materially evidential significance of an item is accepted with a court when through detailed description, sealing and production other similar action eliminated any chance of sufficient changing the signs and particularities of the traces on it and also it was identified by suspected, accused and victim before item's examination in a court (article 128.3 of the CPC). It seems that above stated is not fit in provisions of article 331.8 of the CPC.

According to article 335.1 of the CPC, in course of the proceedings, being heard an opinion of the parties, a court inspects a land or room in cases when it considers impossible to be limited with announcement of the record of land or room inspection that was made in pre-trial production or this inspection has not earlier been produced.

According to article 335.2 of the CPC, inspection of a land and room is produced alternately with prosecution, defence party and a court.

If necessary the inspection of a land and room is produced with participation of witnesses, expert and specialist (article 335.3 of the CPC).

According to article 335.4 of the CPC, with considering of criminal prosecution circumstances and with consent of the parties, a court has the right to charge the production of a land and room inspection to the court of first instance on place of inspected subjects' location. The inspection is fulfilled in presence of attesting 
witness, and a record that made in compliance with requirements of the articles 236.6.1-236.6.7 of the CPC, is announced in a court session.

It seems that the provisions stated are declarative and mostly are not correlated with other provisions of valid legislation.

According to article 236 of the CPC, an inspection is produced in purpose of discovering of crime traces', other material objects, which might be a source of evidence, clarification the circumstances of commission of crime and other circumstances, which are significant for a case. Thus, one may consider that if an inspection is produced repeatedly then the goals of the first inspection were not achieved and evidential significance of the first inspection record is worthless.

This is one thing, and other one is concluded in that being involved in collection of the evidences, a court loses objectiveness and impartiality.

Provision on alternately production of the inspection is presented to be farfetched as then the attesting witnesses, specialists and others will have to be three times participated in this investigated action. In addition, the two other parties, awaiting their turn, cannot confirm the conclusions of inspecting party or will have to be alternately made inspection with it and draw attention on indicated circumstances. It seems that it would be better to all participants to make inspection simultaneously and based on result of it to make one record where to indicate all statements of the parties.

Status of the experts (specialists) will also cause questions, which before inspection might be interrogated with a court as witnesses. In this case, at the same time they will have a status of the two procedural figures.

It seems that the provision about inspection's re-entrusting to a court of first instance on place of inspected subjects' location contraries to principle of direct evidences' examination and violates the rights of process' participants as it does not provide their participation in this procedural action.

In addition, in our point of view, visit a land with participation of accused, victim or witnesses are, on core, testimonies' checking at place, production of which is not provided in a court. 
According to article 336 of the CPC, in course of court proceedings is possible to present to identification, investigative experiment and seizure of the samples for examination with participation of the parties of criminal process and observance the rules stipulated in the CPC for pre-trial production of appropriate investigative actions.

It appears that stated provision has also declarative nature and technically unfeasible. So, article 274 of the CPC enumerates such kinds of the samples, which impossible to obtain in presence all parties (participants) of a process, not causing the reasonable doubts in their belonging.

In addition, sometimes the samples might only be obtained through search and seizure, production of which is not stipulated in a court.

Article 336.3 of the CPC says that if presentation to identification, investigative experiment or seizure of the samples for examination impossible to produce with observance of the proceedings rules then with consents of the parties a court may at certain time authorizes production of indicated actions to prosecutor, who carries out procedural leadership with preliminary investigation in course of pre-trial production.

This means that during court proceedings prosecution party will be produce investigative actions that actually is a pre-trial production.

But if all participants and available audience in a court session wish to take part in production of similar actions then there would appear collisions with principle of publicity of criminal proceedings, declared with article 27 of the CPC.

\section{References}

1. Arkhiv Bakinskogo suda po tyazhkim prestupleniyam i voennogo suda bakinskogo garnizaona za 2009-2010 g. [Archive of Baku Court on Grave Crimes and Military Court of Baku garrison for 2009-2010]. 